\title{
1,1-Ethylboration of ethynyl(trimethyl)tin. (E)-1-Trimethylstannyl- 2-diethylboryl-but-1-ene, isomerization and conversion into hydridoborates
}

\author{
Bernd Wrackmeyer,* Oleg L. Tok, and Peter Thoma \\ Anorganische Chemie II, Universität Bayreuth, D-95440 Bayreuth, Germany \\ E-mail: b.wrack@uni-bayreuth.de
}

Dedicated to Rosalinda Contreras

\begin{abstract}
1,1-Ethylboration of ethynyl(trimethyl)tin affords quantitatively and selectively (E)-1trimethylstannyl-2-diethylboryl-but-1-ene 1a, which isomerizes fast at room temperature into the (Z)-isomer 2a, followed by slow isomerization into the (E/Z)-1-diethylboryl-2-trimethylstannylbut-1-enes 3a and 4a. These rearrangements are independent of the solvent (hexane, benzene, or benzene/THF) and take place at comparable rates at daylight or in the dark. A mechanism is proposed invoking hyperconjugation and three-membered cyclic structures, for which threecoordinate boron atoms as in 1a - 2a are a prerequisite. In order to prove this point, hydridoborates were prepared. The reaction of a mixture $(80: 20)$ of 1a and 2a with sodium hydride gives the corresponding hydridoborates $5 \mathbf{a}$ and $\mathbf{6 a}$, respectively, which in contrast to the boranes do not undergo further rearrangements. An extended NMR data set of the compounds 1a - 6a was measured $\left({ }^{1} \mathrm{H},{ }^{11} \mathrm{~B},{ }^{13} \mathrm{C},{ }^{119} \mathrm{Sn} \mathrm{NMR}\right)$ and discussed. In addition, the synthesis of a mixture of the silicon analogues $\mathbf{1 a}(\mathbf{S i})$ and $\mathbf{2 a}(\mathbf{S i})$ was reproduced, the corresponding NMR data were obtained, the molecular structures were optimized by DFT methods [B3LYP/6$311+\mathrm{G}(\mathrm{d}, \mathrm{p})]$, and relevant chemical shifts were calculated at the same level of theory.
\end{abstract}

Keywords: Triethylborane, alkynes, alkenes, organotin, isomerization, multinuclear NMR, DFT calculations

\section{Introduction}

Organometallic-substituted alkenylboranes are useful synthons for further transformations. ${ }^{1-3}$ In this context, 1,1-organoboration of alkyn-1-ylmetal compounds has opened a convenient route to such alkenes. ${ }^{4}$ Thus, triethylborane, $\mathrm{BEt}_{3}$, reacts readily with numerous alkyn-1-yltin compounds below $0{ }^{\circ} \mathrm{C}$ in inert solvents by cleavage of the $\mathrm{Sn}-\mathrm{C} \equiv$ bond via a short-lived zwitterionic alkyn- 
1-ylborate-like intermediate $\mathbf{A}$ to give alkenes of type 1. In most cases, these organometallicsubstituted alkenes are formed quantitatively and stereoselectively, bearing the boryl and the stannyl groups in cis positions at the $\mathrm{C}=\mathrm{C}$ bond (Scheme 1). ${ }^{4}$ The analogous reaction with alkyn1-ylsilanes, although under much more severe reaction conditions (in boiling $\mathrm{BEt}_{3}$ at ca. $100{ }^{\circ} \mathrm{C}$ ), affords the corresponding alkenylsilanes $\mathbf{1 ( S i )} .^{5}$ The mechanism is well established, ${ }^{6,7}$ and after removing of readily volatile materials (solvent and the excess of $\mathrm{BEt}_{3}$ ), the alkenes $\mathbf{1}$ can be used without further purification.

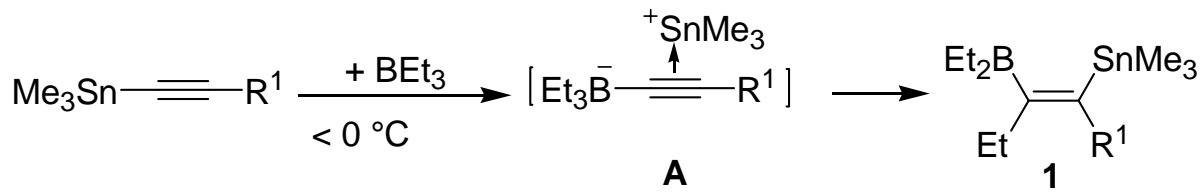

\section{Scheme 1}

For $\mathrm{R}^{1}=$ alkyl or phenyl, the pure alkenes $\mathbf{1}$ are stable under Ar or $\mathrm{N}_{2}$ atmosphere for several days at room temperature. However, in the case of $\mathrm{R}^{1}=\mathrm{H}(\mathbf{1 a})$, it has been noted that $(E / Z)$ isomerization starts within minutes at room temperature (2a), followed more slowly by further rearrangements (3a, $\mathbf{4 a}){ }^{8}$ Since $\mathbf{1 a}$ is one of the most simple 1,1-organoboration products of alkyn-1-yltin compounds, we have studied the formation of 1a and its isomerization in greater detail, aiming for a more complete set of NMR data. It was also of interest to find out whether the three-coordinate boron atom in 1a is a prerequisite for the isomerization. Furthermore, for comparison we have measured a complete NMR data set for the analogous isomers $\mathbf{1 a ( S i )}$ and $\mathbf{2 a ( S i ) ~ w h i c h ~ r e s u l t ~ f r o m ~ 1 , 1 - e t h y l b o r a t i o n ~ o f ~ e t h y n y l ( t r i m e t h y l ) s i l a n e . ~}{ }^{5}$

\section{Results and Discussion}

\section{1,1-Ethylboration, isomerization, proposed mechanism and formation of hydridoborates} In the original report, ${ }^{9}$ the 1,1-ethylboration of ethynyl(trimethyl)tin was carried out in THF, since this particular ethynyltin compound is most readily available as a THF solution. ${ }^{10}$ In all other cases of 1,1-ethylboration of alkyn-1-yl(triorgano)tin derivatives, the solvents have been hexane, toluene, benzene or dichloromethane. This includes triethyl- and tributyl(ethynyl)tin, for which the 1,1-ethylboration products were found to be stable towards isomerization. ${ }^{11}$ Therefore, a priori it could not be excluded that traces of THF catalyze the isomerization.

We have now prepared ethynyl(trimethyl)tin as a solution in hexane, using the reaction of freshly prepared $\mathrm{Li}_{2} \mathrm{C}_{2}$ in hexane with trimethyltin chloride in the presence of ethyne in excess. Although this leads mainly to bis(trimethylstannyl)ethyne, the desired ethynyl(trimethyl)tin (about $15-20 \%$ yield) was found $\left(\delta^{119} \mathrm{Sn}-68.3\right)$ in the hexane fraction which was removed from the reaction mixture in a vacuum and collected in a cold trap at $-196{ }^{\circ} \mathrm{C}$. The compound $1 \mathrm{a}$ was then prepared by addition of $\mathrm{BEt}_{3}$ at $-78{ }^{\circ} \mathrm{C}$ to this hexane solution, warming to room 
temperature, and isolated.. It was dissolved in $\mathrm{C}_{6} \mathrm{D}_{6}$, and the isomerization of 1a was studied without or with addition of a small amount of THF. The results were virtually identical (see Fig. 1). A sample of 1a in hexane gave the same ${ }^{119} \mathrm{Sn}$ NMR spectra. Therefore, a significant influence of THF on the isomerization process can be excluded. There was also no appreciable difference in the type of products and rate of isomerization, when the samples were kept in the dark or at day light.
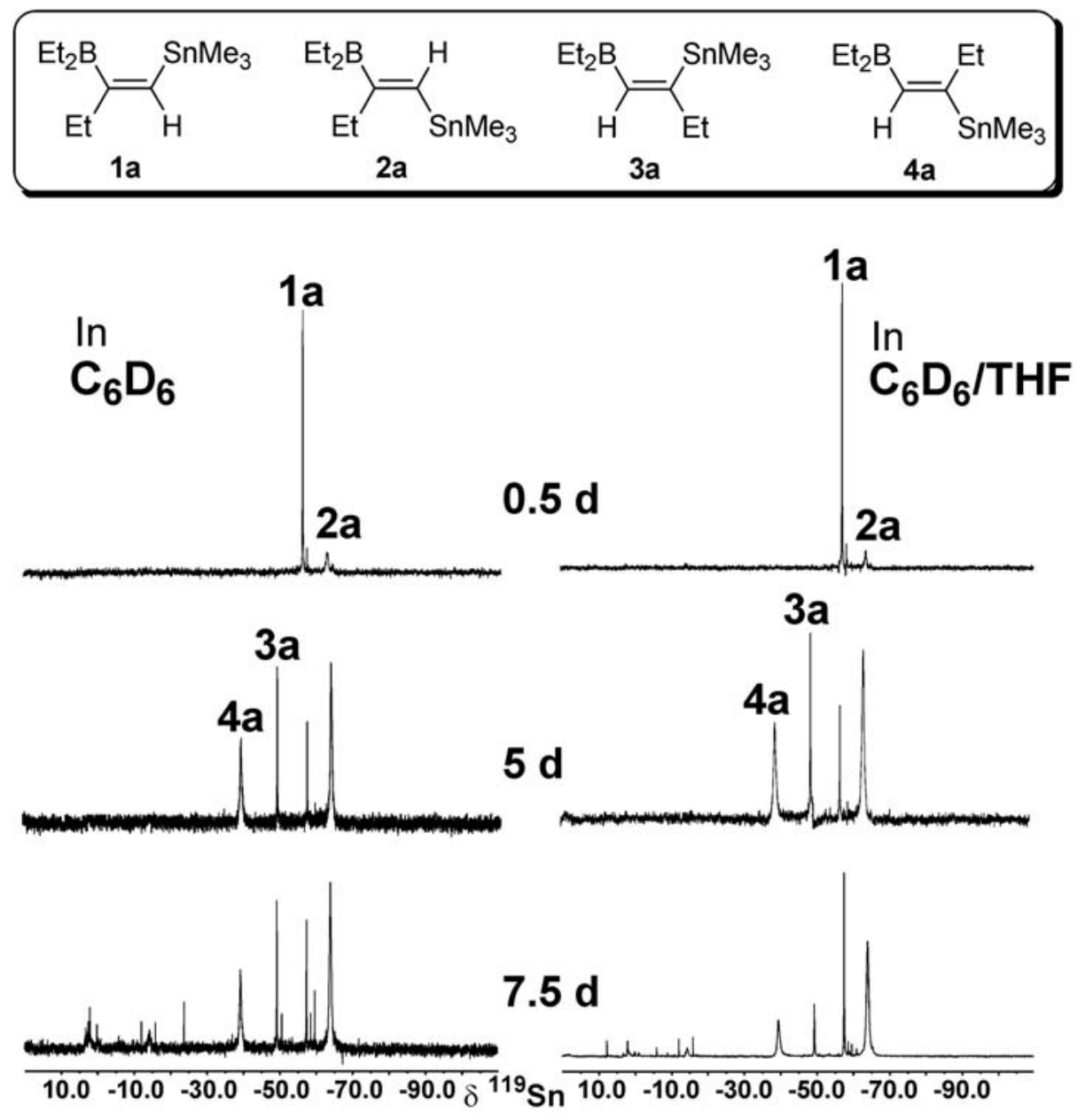

Figure 1. 149.2 MHz ${ }^{119} \mathrm{Sn}\left\{{ }^{1} \mathrm{H}\right\}$ NMR spectra of 1a, dissolved in $\mathrm{C}_{6} \mathrm{D}_{6}$ (left) and $\mathrm{C}_{6} \mathrm{D}_{6} / \mathrm{THF}$ (1:1) (right) measured at room temperature at the times indicated. After $7 \mathrm{~d}$, decomposition becomes apparent, and the product distribution is affected by the presence of THF.

The slow isomerization of other non-cyclic or cyclic alkenyltin compounds with a boryl group present at the $\mathrm{C}=\mathrm{C}$ bond has been discussed, ${ }^{12}$ and the general idea is lined out here for the isomerization of $\mathbf{1 a}$ (Scheme 2). The contribution of the canonic structure $\mathbf{B}$ to the ground state is most likely negligible, although this type of structure is often invoked for vinylboranes. Clearly, B would in principle account for (E/Z)-isomerization (dashed arrows in Scheme 2). However, alkenylboranes, in general, do not exhibit such a pronounced tendency for $(E / Z)$ - 
isomerization and further rearrangements. In the case of $\mathbf{1 a}$, it is also necessary to consider the preferred perpendicular orientation of the $\mathrm{Et}_{2} \mathrm{~B}$ group with respect to the $\mathrm{C}=\mathrm{CB}$ plane, ${ }^{13,14}$ preventing efficient $\mathrm{CB}(\mathrm{pp}) \pi$ interactions (see however $\mathbf{2 a}$, where this may play a role). On the other hand, this particular conformation around the boryl group of 1a favors hyperconjugative $\mathrm{C}$ $\mathrm{B}$ interactions represented in the structure $\mathbf{C}$, where the stannyl group in $\beta$-position relative to the positively charged carbon atom exerts a stabilising effect. ${ }^{15-20}$ Structure $\mathbf{C}$ helps to explain the observed fast isomerization of 1a into 2a. Migration of the stannyl group transforms $\mathbf{C}$ into $\mathbf{D}$, which is of comparable energy or even more stable because of the additional ethyl group in $\beta$ position to the positive charge. The intermediacy of $\mathbf{D}$ explains the observed concomitant formation of $\mathbf{3 a}$ and $\mathbf{4 a}$, of which $\mathbf{4 a}$ appears to be preferred, most likely for steric reasons. It should be noted that other isomers bearing the boryl and the stannyl groups at the same olefinic carbon atom were not observed, and, indeed, neither $\mathbf{C}$ nor $\mathbf{D}$ provide an obvious route to such isomers. This also rules out 1,2-dehydroboration, conceivable at a first glance for $\mathbf{2 a}$, which should give rise to the formation of such alkenes.

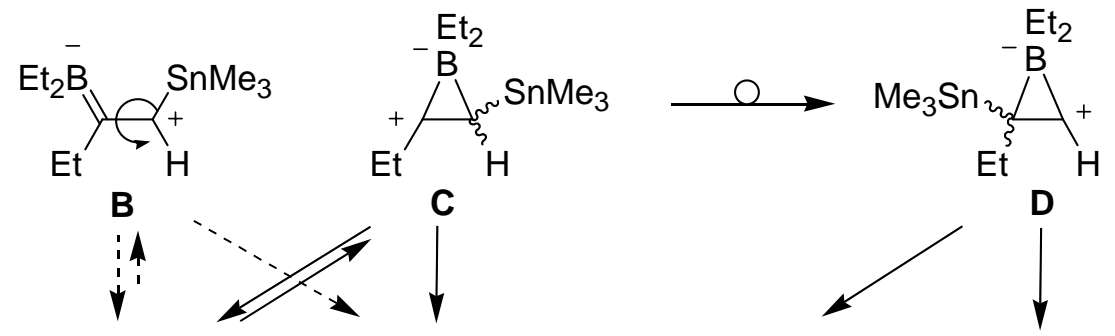

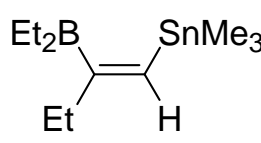

$1 \mathbf{a}$

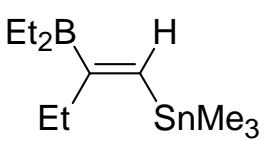

$2 a$<smiles>CC/C=C(\CC)SC</smiles>

$3 a$

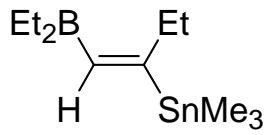

$4 a$

\section{Scheme 2}

If the arguments for $\mathbf{C}$ and $\mathbf{D}$ (Scheme 2) are relevant, the isomerization of 1a as well as further rearrangements of $\mathbf{2 a}$ will be suppressed when the boron atom becomes tetra-coordinate as in borates. Therefore, the reaction of $1 \mathbf{a}$ with sodium hydride $(\mathrm{NaH})$ was studied. Since the heterogeneous reaction with $\mathrm{NaH}$ was slow and isomerization of $\mathbf{1 a}$ occurred before significant amounts of hydridoborates were formed, $\mathrm{NaH}$ was activated ${ }^{21}$ in boiling hexane with $\mathrm{BEt}_{3}$ prior to its reaction with 1a. By this, a mixture of 1a/2a (80:20) was converted completely into the hydridoborates $5 \mathbf{a}$ and $\mathbf{6 a}$ (Scheme 3). The isolated materials were redissolved in $\mathrm{C}_{6} \mathrm{D}_{6}$, and NMR spectra indicated the presence of the desired hydridoborates in an unchanged 80:20 ratio. The $\mathrm{C}_{6} \mathrm{D}_{6}$ solution was monitored over several weeks by ${ }^{1} \mathrm{H},{ }^{11} \mathrm{~B}$ and ${ }^{119} \mathrm{Sn}$ NMR spectroscopy, and further isomerization was not detected. 
<smiles>CCC(=C[SiH3]C)CC</smiles>

$1 \mathbf{a}$<smiles>CCC(=CSC)CC</smiles>

$2 \mathbf{a}$

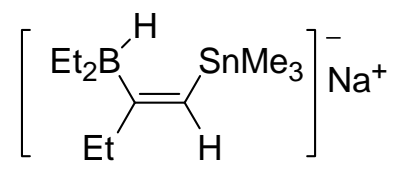

$5 a$

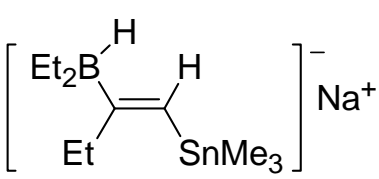

$6 \mathbf{a}$

\section{Scheme 3}

\section{NMR spectroscopic results}

The consistent set of NMR data leaves no doubt on the proposed solution state structures of the compounds $1 \mathbf{a}-\mathbf{6 a}$, and their ${ }^{11} \mathrm{~B},{ }^{13} \mathrm{C}$ and ${ }^{119} \mathrm{Sn}$ NMR parameters are given in Table 1 (see the Experimental Section for ${ }^{1} \mathrm{H}$ NMR data), together with data for the silicon analogues $\mathbf{1 a ( S i )}$ and 2a(Si).

The chemical shifts $\delta^{11} \mathrm{~B}$ for $\mathbf{1 a}-\mathbf{4 a}$ are in the typical range for three-coordinate boron atoms bearing three organyl groups without or with weak $\mathrm{BC}(\mathrm{pp}) \pi$ interactions, whereas those for $\mathbf{5 a}$ and $6 \mathbf{a}$ are characteristic for borates. ${ }^{22}$ The slight increase in ${ }^{11} \mathrm{~B}$ nuclear shielding observed for 2a $\left(\delta^{11} \mathrm{~B} 78.9\right)$ relative to that for $\mathbf{1 a}, \mathbf{3 a}$ and $\mathbf{4 a}$ indicates that the mean angle formed between the $\mathrm{C}_{2} \mathrm{~B}$ plane of the $\mathrm{Et}_{2} \mathrm{~B}$ group and the $\mathrm{C}=\mathrm{CB}$ plane in $\mathbf{2 a}$ deviates markedly from $90^{\circ}$ and allows for $\mathrm{CB}(\mathrm{pp}) \pi$ interactions. The reduced line width of the ${ }^{11} \mathrm{~B}$ NMR signal of $\mathbf{2 a}$ indicates longer relaxation times $\mathrm{T}^{\mathrm{Q}}\left({ }^{11} \mathrm{~B}\right)$, most likely as a result of a more freely rotating $\mathrm{Et}_{2} \mathrm{~B}$ group in $\mathbf{2 a}$ when compared with the situation in $\mathbf{1 a}$. $\mathrm{CB}(\mathrm{pp}) \pi$ interactions in $\mathbf{2 a}$ and $\mathbf{2 a}(\mathbf{S i})$ are supported by the $\delta^{13} \mathrm{C}(\mathrm{SnC}=)$ and $\delta^{13} \mathrm{C}(\mathrm{SiC}=)$ data for the pairs $\mathbf{1 a} / \mathbf{2 a}$ and $\mathbf{1 a}(\mathbf{S i}) / \mathbf{2 a}(\mathbf{S i})$. Typically, the possibility for extended $\pi$ interactions between the $\mathrm{C}=\mathrm{C}$ bond and an appropriate $\pi$ acceptor orbital at a neighbored atom induces deshielding of the olefinic ${ }^{13} \mathrm{C}$ nucleus in $\beta$-position relative to the $\pi$ acceptor ${ }^{23}$ (here by 12.5 and $10.2 \mathrm{ppm}$ ). Such a difference in the $\delta^{13} \mathrm{C}(\mathrm{SnC}=)$ values is absent for the pair $3 \mathbf{a} / \mathbf{4} \mathbf{a}$, and one can conclude that the preferred conformation of the $\mathrm{Et}_{2} \mathrm{~B}$ group is similar in these isomers. The enforced absence of an extended $\pi$ system in the borates $5 \mathbf{a}$ and $\mathbf{6 a}$ is mirrored by the shielding of the ${ }^{13} \mathrm{C}(\mathrm{SnC}=)$ nuclei, which is very similar to that in $\mathbf{1 a}$, for which the arrangement of the $\mathrm{Et}_{2} \mathrm{~B}$ group is unfavorable for $\mathrm{CB}(\mathrm{pp}) \pi$ interactions.

The assignment of all ${ }^{13} \mathrm{C}$ NMR signals is straightforward, using the information from ${ }^{117 / 119} \mathrm{Sn}$ and ${ }^{29} \mathrm{Si}$ satellites $\left[J\left(\mathrm{Sn}^{13} \mathrm{C}\right)\right.$ (Fig. 2) or $\left.J\left({ }^{29} \mathrm{Si},{ }^{13} \mathrm{C}\right)\right]$, the typically broad lines for ${ }^{13} \mathrm{C}$ nuclei linked directly to boron (scalar relaxation of the second kind owing to ${ }^{13} \mathrm{C}-{ }^{11} \mathrm{~B}$ spin-spin coupling ${ }^{24,25}$ ). The mutual positions of substituents at the $\mathrm{C}=\mathrm{C}$ bond are further confirmed by ${ }^{1} \mathrm{H} /{ }^{1} \mathrm{H} \mathrm{NOE}$ difference spectra. ${ }^{26}$ 
Table 1. ${ }^{11} \mathrm{~B},{ }^{13} \mathrm{C},{ }^{29} \mathrm{Si}$ and ${ }^{119} \mathrm{Sn}$ NMR parameters ${ }^{[\mathrm{a}]}$ of the alkenes $\mathbf{1}-\mathbf{6}$

\begin{tabular}{|c|c|c|c|c|c|c|c|}
\hline & $\begin{array}{l}\delta^{13} \mathrm{C} \\
\mathrm{Me}_{3} \mathrm{Sn} \\
\mathrm{Me}_{3} \mathrm{Si}\end{array}$ & $\begin{array}{l}\mathrm{Sn}-\mathrm{C}= \\
\mathrm{Si}-\mathrm{C}=\end{array}$ & $=\mathrm{C}-\mathrm{B}$ & $\mathrm{BEt}_{2}$ & $\mathrm{Et}$ & $\begin{array}{l}\delta^{119} \mathrm{Sn} \\
\left(\mathrm{h}_{1 / 2}\right)[\mathrm{Hz}] \\
\delta^{29} \mathrm{Si}\end{array}$ & $\begin{array}{l}\delta^{11} \mathrm{~B} \\
\left(\mathrm{~h}_{1 / 2}\right)[\mathrm{Hz}]\end{array}$ \\
\hline 1a & $\begin{array}{l}-8.5 \\
{[338.0]}\end{array}$ & $\begin{array}{l}124.9 \\
{[502.1]}\end{array}$ & $\begin{array}{l}173.9 \\
\text { (br) }\end{array}$ & $\begin{array}{l}21.6,8.8 \\
\text { (br) }\end{array}$ & $\begin{array}{l}32.7,13.3 \\
{[96.3]}\end{array}$ & $\begin{array}{l}-57.3 \\
(13)\end{array}$ & $\begin{array}{l}84.9 \\
(480)\end{array}$ \\
\hline $1 a(S i)$ & $\begin{array}{l}0.6 \\
\{51.2\}\end{array}$ & $\begin{array}{l}125.2 \\
\{69.7\}\end{array}$ & $\begin{array}{l}171.4 \\
\text { (br) }\end{array}$ & $\begin{array}{l}22.1,9.7 \\
\text { (br) }\end{array}$ & $\begin{array}{l}31.3,13.3 \\
\{9.4\}\end{array}$ & $\begin{array}{l}-9.7 \\
(0.8)\end{array}$ & $\begin{array}{l}84.4 \\
(390)\end{array}$ \\
\hline $2 a$ & $\begin{array}{l}-8.3 \\
{[336.1]}\end{array}$ & $\begin{array}{l}137.4 \\
{[441.8]}\end{array}$ & $\begin{array}{l}173.1 \\
\text { (br) }\end{array}$ & $\begin{array}{l}18.8,9.7 \\
\text { (br) }\end{array}$ & $\begin{array}{l}32.7,15.9 \\
{[63.9]}\end{array}$ & $\begin{array}{l}-63.9 \mathrm{br} \\
(90)\end{array}$ & $\begin{array}{l}78.9 \\
(380)\end{array}$ \\
\hline $2 a(S i)$ & $\begin{array}{l}1.1 \\
\{50.8\}\end{array}$ & $\begin{array}{l}135.4 \\
\{64.0\}\end{array}$ & $\begin{array}{l}173.7 \\
\text { (br) }\end{array}$ & $\begin{array}{l}19.4,9.2 \\
\text { (br) }\end{array}$ & $\begin{array}{l}29.4,16.1 \\
\{5.6\}\end{array}$ & $\begin{array}{l}-11.0 \\
(1.3)\end{array}$ & $\begin{array}{l}80.2 \\
(320)\end{array}$ \\
\hline 3a & $\begin{array}{l}-7.4 \\
{[328.6]}\end{array}$ & $\begin{array}{l}162.3 \\
{[448.9]}\end{array}$ & $\begin{array}{l}148.2 \\
\text { (br) }\end{array}$ & $\begin{array}{l}21.6,9.1 \\
\text { (br) }\end{array}$ & $\begin{array}{l}38.4,14.8 \\
{[62.0]}\end{array}$ & $\begin{array}{l}-49.3 \\
(16)\end{array}$ & $\begin{array}{l}86.5 \\
\left(\text { n.m. }{ }^{[b]}\right)\end{array}$ \\
\hline $4 a$ & $\begin{array}{l}-9.0 \\
{[325.8]}\end{array}$ & $\begin{array}{l}161.9 \\
{[466.6]}\end{array}$ & $\begin{array}{l}149.1 \\
\text { (br) }\end{array}$ & $\begin{array}{l}21.6,9.0 \\
\text { (br) }\end{array}$ & $\begin{array}{l}33.3,15.9 \\
{[63.1]}\end{array}$ & $\begin{array}{l}-39.3 \\
(81)\end{array}$ & $\begin{array}{l}81.0 \\
\left(n . m .{ }^{[b]}\right)\end{array}$ \\
\hline $5 a$ & $\begin{array}{l}-6.4 \\
{[330.2]}\end{array}$ & $\begin{array}{l}124.9 \\
{[521.1]}\end{array}$ & $\begin{array}{l}192.4 \\
\text { (br) }\end{array}$ & $\begin{array}{l}13.8,12.4 \\
\text { (br) }\end{array}$ & $\begin{array}{l}33.4,9.7 \\
{[100.6]}\end{array}$ & $\begin{array}{l}-68.8 \\
(43)\end{array}$ & $\begin{array}{l}-12.1 \\
(160)\end{array}$ \\
\hline $6 a$ & $\begin{array}{l}-8.0 \\
{[325.6]}\end{array}$ & $\begin{array}{l}126.9 \\
{[444.8]}\end{array}$ & $\begin{array}{l}193.8 \\
\text { (br) }\end{array}$ & $\begin{array}{l}16.5,13.6 \\
\text { (br) }\end{array}$ & $\begin{array}{l}34.2,10.8 \\
{[65.5]}\end{array}$ & $\begin{array}{l}-72.9 \\
(174) \\
\end{array}$ & $\begin{array}{l}-10.1 \\
\left(\mathrm{n} . \mathrm{m}^{[\mathrm{b}]}\right)\end{array}$ \\
\hline
\end{tabular}

[a] Samples (5-10\%) in $\mathrm{C}_{6} \mathrm{D}_{6}$ at $296 \mathrm{~K}$; coupling constants $J\left({ }^{119} \mathrm{Sn},{ }^{13} \mathrm{C}\right)$ are given in brackets $[ \pm$ $0.5 \mathrm{~Hz}]$, and $J\left({ }^{29} \mathrm{Si},{ }^{13} \mathrm{C}\right)$ in braces $\{ \pm 0.5 \mathrm{~Hz}\}$; (br) denotes ${ }^{13} \mathrm{C}$ NMR signals broadened by partially relaxed scalar ${ }^{13} \mathrm{C}-{ }^{11} \mathrm{~B}$ spin-spin coupling; ${ }^{25} \mathrm{~h}_{1 / 2}$ means full line width at half height.

[b] n.m. = not measured, because of overlapping ${ }^{11} \mathrm{~B}$ NMR signals.

The ${ }^{119} \mathrm{Sn}$ NMR parameters ${ }^{27}$ of $\mathbf{1 a}-\mathbf{6 a}$ are instructive in several respects. ${ }^{119} \mathrm{Sn}$ nuclear shielding increases in the borates $5 \mathbf{a}$ and $\mathbf{6 a}$ by 11.5 and $9.0 \mathrm{ppm}$, when compared with the boranes 1a and 2a, respectively. This fairly constant change means that $\mathrm{CB}(\mathrm{pp}) \pi$ interactions in 2a have little influence on $\delta^{119} \mathrm{Sn}$. It appears that the $\delta^{119} \mathrm{Sn}$ data of $1 \mathbf{a}-\mathbf{6 a}$ depend on substituent effects exerted by the proximity and the respective nature of the substituent rather than on small changes in the bonding situation of the $\mathrm{C}=\mathrm{C}$ bond. There are also changes in the magnitude of ${ }^{1} J\left({ }^{119} \mathrm{Sn},{ }^{13} \mathrm{C}_{(\mathrm{SnC}=)}\right)$ depending on the other substituents. This parameter may change readily with the bond angle at the olefinic carbon $\mathrm{SnC}=$ as a function of the bulkiness of other substituents in geminal or cis positions relative to the stannyl group. In contrast to changes in ${ }^{1} \mathrm{~J}\left({ }^{119} \mathrm{Sn},{ }^{13} \mathrm{C}_{(\mathrm{SnC}=)}\right)$, the magnitude of ${ }^{1} \mathrm{~J}\left({ }^{119} \mathrm{Sn},{ }^{13} \mathrm{C}_{(\mathrm{SnMe})}\right)$ remains fairly constant throughout the series of compounds 1a - 6a. The magnitude of the coupling constants ${ }^{3} J\left({ }^{119} \mathrm{Sn},{ }^{13} \mathrm{C}_{(\mathrm{Et})}\right)$ across the $\mathrm{C}=\mathrm{C}$ bond is expectedly greater for the trans (1a) than for the cis coupling-pathway (2a). ${ }^{27,28}$ A similar behavior is expected for ${ }^{119} \mathrm{Sn}-{ }^{11} \mathrm{~B}$ spin-spin coupling. ${ }^{8}$ Although splitting due to this coupling is not resolved, the comparison of the line widths (Fig. 3) of the ${ }^{119} \mathrm{Sn} \mathrm{NMR}$ signals shows that 
$\left|{ }^{3} J\left({ }^{119} \mathrm{Sn},{ }^{11} \mathrm{~B}\right)_{\text {trans }}\right|>\left|{ }^{3} J\left({ }^{119} \mathrm{Sn},{ }^{11} \mathrm{~B}\right)_{\text {cis }}\right|$. In the borates $5 \mathbf{a}$ and $\mathbf{6 a}$, the times $\mathrm{T}^{\mathrm{Q}}\left({ }^{11} \mathrm{~B}\right)$ are longer than in the boranes. Therefore, the life time of the ${ }^{11} \mathrm{~B}$ nuclear spin states increases, and the residual broadening of the ${ }^{119} \mathrm{Sn}$ NMR signals as a result of scalar ${ }^{119} \mathrm{Sn}-{ }^{11} \mathrm{~B}$ coupling is larger in 5a and 6a when compared with the boranes $1 \mathbf{a}$ and $\mathbf{2 a}$, respectively.

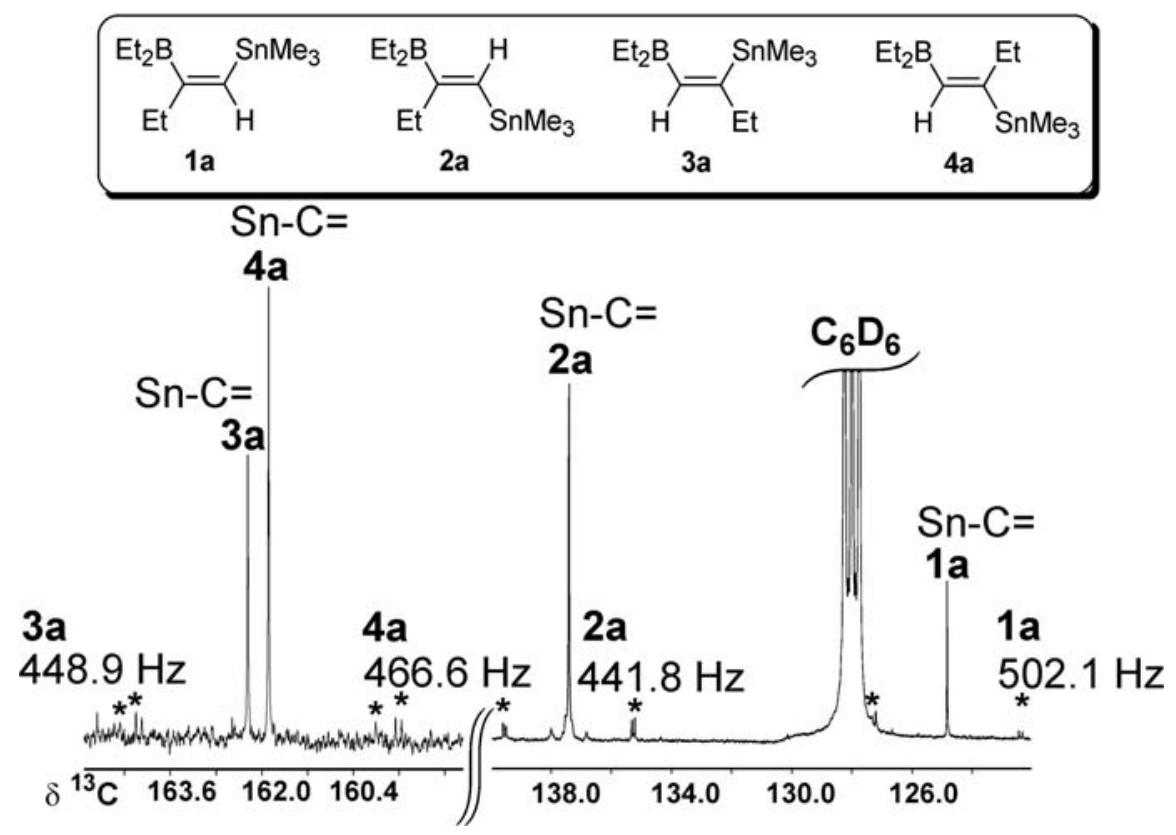

Figure 2. Parts of the $100 \mathrm{MHz}{ }^{13} \mathrm{C}\left\{{ }^{1} \mathrm{H}\right\}$ NMR spectrum of the mixture of isomers $\mathbf{1 a}-\mathbf{4 a}$ in $\mathrm{C}_{6} \mathrm{D}_{6}(10 \% \mathrm{v} / \mathrm{v}$; at $296 \mathrm{~K})$ showing the ${ }^{13} \mathrm{C}(\mathrm{Sn}-\mathrm{C}=)$ NMR signals with the ${ }^{117 / 119} \mathrm{Sn}$ satellites (marked by asterisks) corresponding to ${ }^{1} J\left(\mathrm{Sn},{ }^{13} \mathrm{C}\right)$, and the data ${ }^{1} J\left({ }^{119} \mathrm{Sn},{ }^{13} \mathrm{C}\right)$ are given.

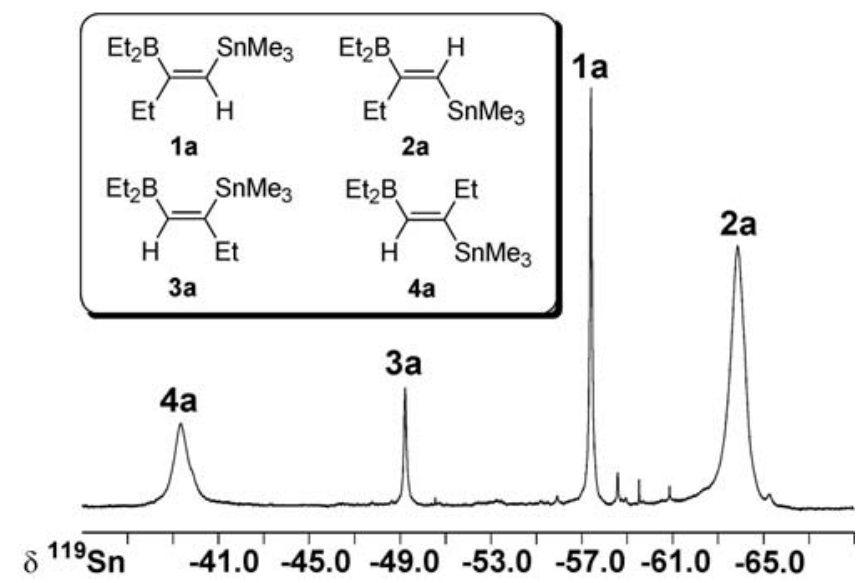

Figure 3. 149.2 MHz ${ }^{119} \mathrm{Sn}\left\{{ }^{1} \mathrm{H}\right\}$ NMR spectrum of the mixture of isomers 1a - 4a showing the different line widths owing to partially relaxed scalar ${ }^{119} \mathrm{Sn}-{ }^{11} \mathrm{~B}$ spin-spin coupling for $\left|{ }^{3} J\left({ }^{119} \mathrm{Sn},{ }^{11} \mathrm{~B}\right)_{\text {trans }}\right|>\left|{ }^{3} \mathrm{~J}\left({ }^{119} \mathrm{Sn},{ }^{11} \mathrm{~B}\right)_{\text {cis }}\right|$. 
In the case of the silanes $\mathbf{1 a}(\mathbf{S i})$ and $\mathbf{2 a}(\mathbf{S i})$, the residual broadening of the ${ }^{29} \mathrm{Si}$ NMR signals is much less pronounced (Fig. 4), since the magnitude of ${ }^{3} \mathrm{~J}^{29} \mathrm{Si}^{11}{ }^{11} \mathrm{~B}$ ) is expectedly markedly smaller than that of ${ }^{3} J\left({ }^{119} \mathrm{Sn},{ }^{11} \mathrm{~B}\right)$ and, at the same time, the quadrupolar relaxation of the ${ }^{11} \mathrm{~B}$ nuclei is similarly efficient in the stannanes and silanes, as can be seen from the line widths of the ${ }^{11} \mathrm{~B}$ NMR signals (Table 1). However, the ${ }^{29} \mathrm{Si}$ NMR spectra, if measured by using the refocused INEPT pulse sequence with ${ }^{1} \mathrm{H}$ decoupling, ${ }^{29}$ serve for measuring ${ }^{13} \mathrm{C}$ satellites corresponding to coupling constants $J\left({ }^{29} \mathrm{Si},{ }^{13} \mathrm{C}\right)$, some of which may be difficult to obtain from ${ }^{13} \mathrm{C}$ NMR spectra.

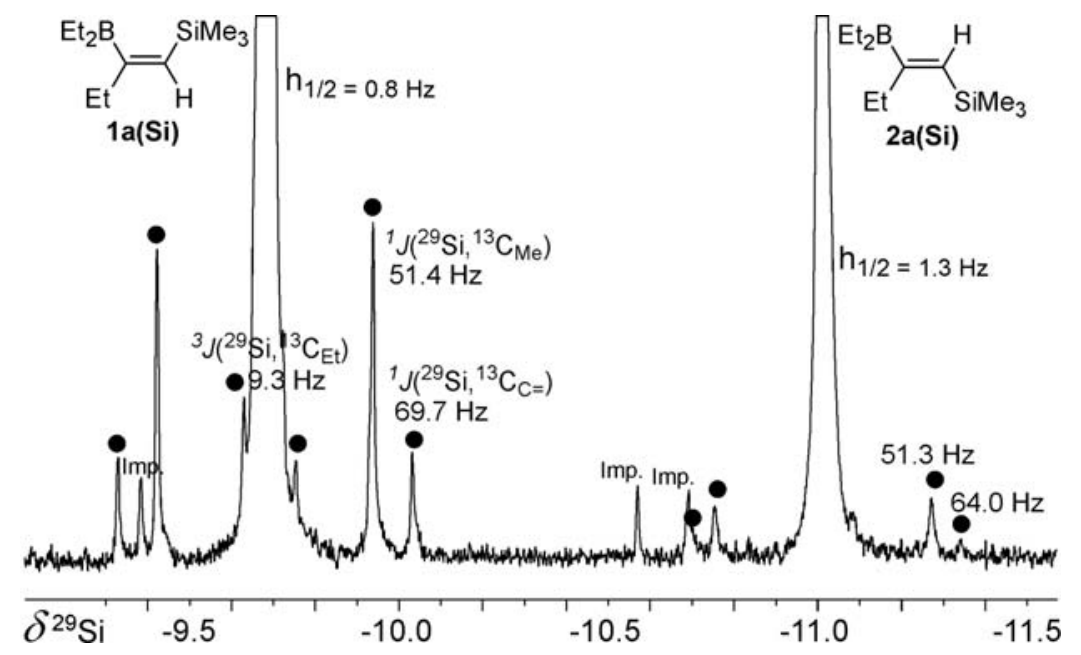

Figure 4. 99.4 MHz ${ }^{29} \mathrm{Si}\left\{{ }^{1} \mathrm{H}\right\}$ NMR spectrum of the mixture of the silanes $\mathbf{1 a}(\mathbf{S i})$ and $\mathbf{2 a}(\mathbf{S i})$ refocused INEPT ${ }^{29}$ ) showing the ${ }^{13} \mathrm{C}$ satellites (marked by filled circles) in agreement with the information from ${ }^{13} \mathrm{C}$ NMR spectra.

\section{DFT Calculations}

The assumption of a significant conformational difference between 1a and 2a concerning the $\mathrm{Et}_{2} \mathrm{~B}$-group is supported by optimizing the geometry of the silicon analogues $\mathbf{1 a}(\mathbf{S i})$ and $\mathbf{2 a}(\mathbf{S i})$ using DFT methods [B3LYP/6-311G(d,p)], ${ }^{30}$ and the result is shown in Fig. 5. Relevant chemical shifts, calculated (GIAO ${ }^{31}$ ) at the same level of theory, show reasonable agreement with the experimental data. The calculated orientation of the ethyl groups may not represent exactly the preferred structures in solution. This appears to affect in particular some of the calculated $\delta^{13} \mathrm{C}$ values. The experimental trend, however, is correctly reproduced. 


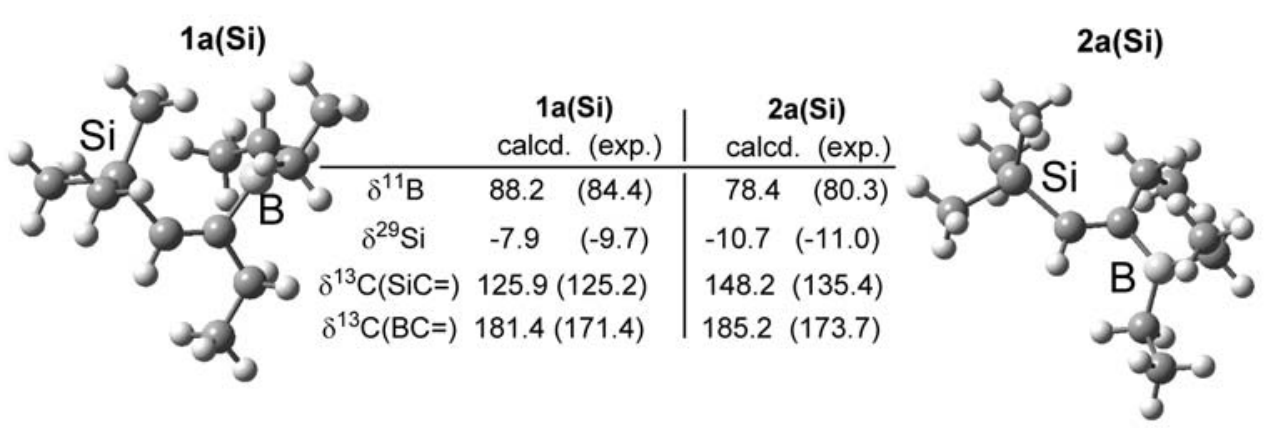

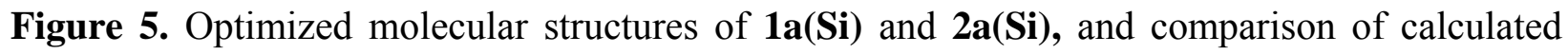
(GIAO ${ }^{31}$ ) and experimental chemical shifts [B3LYP/6-311+G(d,p)]. It shows the almost perpendicular arrangement of the $\mathrm{BC}_{2}$ plane of the $\mathrm{BEt}_{2}$ group relative to the $\mathrm{BC}=\mathrm{C}$ plane in $\mathbf{1 a}(\mathbf{S i})$ (mean angle $85^{\circ}$ ), in contrast to the analogous much less twisted conformation in $2 \mathbf{a}(\mathbf{S i})$ (mean angle $38^{\circ}$ ).

\section{Conclusions}

The fast (E/Z)-isomerization of the title compound 1a into 2a was found to be independent of the solvent or day light. Isomerization was not observed when the boron atom became tetracoordiante in the case of the hydridoborate 5a. Therefore, the electron-deficient character of the boron atom in the $\mathrm{Et}_{2} \mathrm{~B}$ group plays a decisive role. The selective further rearrangement of $\mathbf{2 a}$ into the isomers 3a and 4a, again not observed for the hydridoborate 6a, points towards a threemembered cyclic transition state, in which the stannyl- and the boryl groups can readily migrate from one olefinic carbon to the other. Application of multinuclear NMR serves for the unambiguous structural assignment of the compounds studied and ${ }^{119} \mathrm{Sn}$ NMR spectroscopy, in particular, allows for monitoring of the isomerization process.

\section{Experimental Section}

General Procedures. The preparations and all handling of samples were carried out under an inert atmosphere (Ar), and carefully oven-dried glassware and dry solvents were used throughout. BuLi in hexane $(1.6 \mathrm{M})$, trimethyltin chloride, ethynyl(trimethyl)silane, triethylborane, sodium hydride in mineral oil (Aldrich), and ethyne (purified by passing it through a trap at $-78{ }^{\circ} \mathrm{C}$, followed by washing it with concentrated $\mathrm{H}_{2} \mathrm{SO}_{4}$ ) were commercial products. NMR measurements in $\mathrm{C}_{6} \mathrm{D}_{6}$ (concentration ca. $5-15 \%$ ) were carried out with samples in $5 \mathrm{~mm}$ tubes at $23 \pm 1{ }^{\circ} \mathrm{C}$, using a Bruker DRX 500 and Varian Inova 300 and 400 spectrometers for ${ }^{1} \mathrm{H},{ }^{11} \mathrm{~B},{ }^{13} \mathrm{C},{ }^{29} \mathrm{Si}$ and ${ }^{119} \mathrm{Sn} \mathrm{NMR}$; chemical shifts are given with respect to $\mathrm{SiMe}_{4}\left[\delta^{1} \mathrm{H}\left(\mathrm{C}_{6} \mathrm{D}_{5} \mathrm{H}\right)=7.15 ; \delta^{13} \mathrm{C}\left(\mathrm{C}_{6} \mathrm{D}_{6}\right)=128.0 ; \delta^{29} \mathrm{Si}=0\right.$ for $\left.\Xi\left({ }^{29} \mathrm{Si}\right)=19.867184 \mathrm{MHz}\right]$; 
external $\mathrm{BF}_{3}-\mathrm{OEt}_{2}\left[\delta^{11} \mathrm{~B}=0\right.$ for $\left.\Xi\left({ }^{11} \mathrm{~B}\right)=32.083971 \mathrm{MHz}\right]$, and $\delta^{119} \mathrm{Sn}=0$ for neat $\mathrm{SnMe}_{4}$ with $\Xi\left({ }^{119} \mathrm{Sn}\right)=37.290665 \mathrm{MHz}$. Chemical shifts $\delta^{1} \mathrm{H}$ are given to $\pm 0.03 \mathrm{ppm}, \delta^{13} \mathrm{C}, \delta^{29} \mathrm{Si}$, and $\delta^{119} \mathrm{Sn}$ to $\pm 0.1 \mathrm{ppm}$, and $\delta^{11} \mathrm{~B}$ to $\pm 0.3 \mathrm{ppm} .{ }^{29} \mathrm{Si}$ and most of the ${ }^{119} \mathrm{Sn}$ NMR spectra were measured by using the refocused INEPT pulse sequence, ${ }^{29}$ based on ${ }^{2} \mathrm{~J}\left({ }^{29} \mathrm{Si},{ }^{1} \mathrm{H}_{\mathrm{Me}}\right)(\mathrm{ca} .7 \mathrm{~Hz})$ and ${ }^{2} \mathrm{~J}\left({ }^{119} \mathrm{Sn},{ }^{1} \mathrm{H}_{\mathrm{Me}}\right)$ (ca. $52 \mathrm{~Hz}$ ), respectively. Calculations for optimization of the structures and nuclear shielding were carried out using the Gaussian 03 program package. ${ }^{30}$ Calculated. $\sigma\left({ }^{13} \mathrm{C}\right)$ data were converted to $\delta^{13} \mathrm{C}$ data by $\delta^{13} \mathrm{C}=\sigma\left({ }^{13} \mathrm{C}\right)\left[\mathrm{SiMe}_{4}\right]-\sigma\left({ }^{13} \mathrm{C}\right)$, with $\sigma\left({ }^{13} \mathrm{C}\right)\left[\mathrm{SiMe}_{4}\right]=184.0, \delta^{13} \mathrm{C}$ $\left[\mathrm{SiMe}_{4}\right]=0 ; \sigma\left({ }^{11} \mathrm{~B}\right)$ data to $\delta^{11} \mathrm{~B}$ data by $\delta^{11} \mathrm{~B}=\sigma\left({ }^{11} \mathrm{~B}\right)\left[\mathrm{B}_{2} \mathrm{H}_{6}\right]-\sigma\left({ }^{11} \mathrm{~B}\right)+18$, with $\sigma\left({ }^{11} \mathrm{~B}\right)\left[\mathrm{B}_{2} \mathrm{H}_{6}\right]$ $=84.1, \delta^{11} \mathrm{~B}\left[\mathrm{~B}_{2} \mathrm{H}_{6}\right]=18.0$ and $\delta^{11} \mathrm{~B}\left[\mathrm{BF}_{3}-\mathrm{OEt}_{2}\right]=0 ; \sigma\left({ }^{29} \mathrm{Si}\right)$ data to $\delta^{29} \mathrm{Si}$ data by $\delta^{29} \mathrm{Si}=\sigma\left({ }^{29} \mathrm{Si}\right)$ $\left[\mathrm{SiMe}_{4}\right]-\sigma\left({ }^{29} \mathrm{Si}\right)$, with $\sigma\left({ }^{29} \mathrm{Si}\right)\left[\mathrm{SiMe}_{4}\right]=340.1, \delta^{29} \mathrm{Si}\left[\mathrm{SiMe}_{4}\right]=0$.

Ethynyl(trimethyl)tin as a hexane solution. Under an $\mathrm{Ar}$ atmosphere butyllithium (1.6 $\mathrm{M}$ in hexane; $85.5 \mathrm{~mL}, 136.8 \mathrm{mmol})$ was further diluted with hexane $(100 \mathrm{~mL})$ and cooled at $0{ }^{\circ} \mathrm{C}$. Purified ethyne was slowly bubbled into the stirred solution for $90 \mathrm{~min}$. Immediately, a white precipitate was formed. Then trimethyltin chloride $(27.2 \mathrm{~g}, 136.55 \mathrm{mmol})$ was added as a solid, when the suspension was cooled at $-78^{\circ} \mathrm{C}$. The cooling bath was taken away, und the reaction solution stirred for $12 \mathrm{~h}$. Insoluble materials were filtered off, and all volatiles were collected in a cold trap. The remaining solid was bis(trimethylstannyl)ethyne $\left({ }^{119} \mathrm{Sn}-81.1\right.$ in hexane) which can be purified by sublimation or used directly for further syntheses. The cold trap contained a hexane solution of ethynyl(trimethyl)tin $(20 \mathrm{mmol}$ in $185 \mathrm{~mL})$ as indicated by ${ }^{1} \mathrm{H}$ and ${ }^{119} \mathrm{Sn}$ NMR spectra $\left(\delta^{119} \mathrm{Sn}-68.3\right)$.

(E)-1-Trimethylstannyl-2-diethylboryl-but-1-ene 1a and isomerization into 2a, 3a and 4a. The hexane solution of ethynyl(trimethyl)tin $\left(20 \mathrm{mmol}\right.$ in $185 \mathrm{~mL}$ ) was cooled at $-78{ }^{\circ} \mathrm{C}$, and triethylborane $(5 \mathrm{~mL}, 35 \mathrm{mmol})$ was added in one portion. The stirred mixture was warmed to 0 ${ }^{\circ} \mathrm{C}$ within $10 \mathrm{~min}$, and the solvent and excess of $\mathrm{BEt}_{3}$ were removed in a vacuum, leaving the pure compound 1a in quantitative yield as extremely air-sensitive colorless oil. The pure sample of 1a can be kept under $\mathrm{Ar}$ at $-80{ }^{\circ} \mathrm{C}$ for prolonged periods without isomerization.

Compound 1a was dissolved in $\mathrm{C}_{6} \mathrm{D}_{6}$ and in a mixture of $\mathrm{C}_{6} \mathrm{D}_{6} / \mathrm{THF}$ (1:1), and the timedependent isomerization was studied by ${ }^{119} \mathrm{Sn}$ NMR spectroscopy (Fig. 1). Daylight does neither affect the rate of isomerization nor the product distribution. 1a: ${ }^{1} \mathrm{H}$ NMR $(300 \mathrm{MHz}): \delta^{1} \mathrm{H}$ $\left[J\left({ }^{119} \mathrm{Sn},{ }^{1} \mathrm{H}\right)\right]=0.09[52.5]\left(\mathrm{s}, 9 \mathrm{H}, \mathrm{Me}_{3} \mathrm{Sn}\right), 1.27,0.99\left(\mathrm{q}, \mathrm{t}, J=7.5 \mathrm{~Hz}, 10 \mathrm{H}, \mathrm{Et}_{2} \mathrm{~B}\right), 2.12,0.99$ (q, t, $J=7.3 \mathrm{~Hz}, 5 \mathrm{H}, \mathrm{Et}-\mathrm{C}=), 6.12$ [92.1] (s, $1 \mathrm{H}, \mathrm{H}-\mathrm{C}=) .2 \mathrm{a}:{ }^{1} \mathrm{H}$ NMR $(300 \mathrm{MHz}): \delta^{1} \mathrm{H}\left[{ }^{1}\left({ }^{119} \mathrm{Sn},{ }^{1} \mathrm{H}\right)\right]$ $=0.19[53.0]$ (s, 9H, $\mathrm{Me}_{3} \mathrm{Sn}$ ), 1,27, 0.99 (q, t, $J=7.5 \mathrm{~Hz}, \mathrm{Et}_{2} \mathrm{~B}$ ), 2.32, 0.90 (q, t, $J=7.3 \mathrm{~Hz}, 5 \mathrm{H}$, $\mathrm{Et}-\mathrm{C}=), 6.34$ [98.6] (s, $1 \mathrm{H}, \mathrm{H}-\mathrm{C}=)$. 3a: ${ }^{1} \mathrm{H}$ NMR $(300 \mathrm{MHz}): \delta^{1} \mathrm{H}\left[J\left({ }^{119} \mathrm{Sn},{ }^{1} \mathrm{H}\right)\right]=0.13[52.5](\mathrm{s}$, 9H, $\mathrm{Me}_{3} \mathrm{Sn}$ ), 1.27, 0.99 (q, t, $J=7.5 \mathrm{~Hz}, \mathrm{Et}_{2} \mathrm{~B}$ ), 2.32, 098 (q, t, $\left.J=7.3 \mathrm{~Hz}, 5 \mathrm{H}, \mathrm{Et}-\mathrm{C}=\right), 6.86$ [190.6] (s, 1H, H-C=). 4a: ${ }^{1} \mathrm{H}$ NMR (300 MHz): $\delta^{1} \mathrm{H}\left[J\left({ }^{119} \mathrm{Sn},{ }^{1} \mathrm{H}\right)\right]=0.16[52.5]\left(\mathrm{s}, 9 \mathrm{H}, \mathrm{Me}_{3} \mathrm{Sn}\right)$, $1.27,0.99$ (q, t, $J=7.6 \mathrm{~Hz}, \mathrm{Et}_{2} \mathrm{~B}$ ), 2.32, 0.97 (q, t, $J=7.3 \mathrm{~Hz}, \mathrm{Et}-\mathrm{C}=$ ), 6.26 [109.4] (s, 1H, H$\mathrm{C}=$ ).

Mixture (80:20) of (E)- and (Z)-1-trimethylsilyl-2-diethylboryl-but-1-ene 1a(Si) and 2a(Si). A mixture of ethynyl(trimethyl)silane $(2.4 \mathrm{~g}, 24.4 \mathrm{mmol})$ and an excess of triethylborane $(4 \mathrm{~mL}$, 
29 .mmol) were heated in a closed Schlenk tube under Ar at $120{ }^{\circ} \mathrm{C}$ (oil bath) for $100 \mathrm{~h}$. The reaction was monitored by ${ }^{29} \mathrm{Si}$ NMR (see Table 1 and Fig. 4) until about $40 \%$ conversion of the alkyne was achieved. The excess of $\mathrm{BEt}_{3}$ and unreacted alkyne were removed in a vacuum, and the products were left as air-sensitive colorless oil. In one of these experiments, the mixture contained a small amount $(<10 \%)$ of a third compound $\left(\delta^{29} \mathrm{Si}-7.4\right)$, most likely a hydroboration product ${ }^{32}$ not mentioned in the first report. ${ }^{5} \mathbf{1 a}(\mathbf{S i}):{ }^{1} \mathrm{H}$ NMR $(400 \mathrm{MHz}): \delta^{1} \mathrm{H}=0.00(\mathrm{~s}, 9 \mathrm{H}$, $\mathrm{Me}_{3} \mathrm{Si}$ ), 1.21, 0.93 (q, t, $J=7.5 \mathrm{~Hz} 10 \mathrm{H}, \mathrm{Et}_{2} \mathrm{~B}$ ), 1.91, 0.90 (dq, t, $J=0.8 \mathrm{~Hz}, J=7.3 \mathrm{~Hz}, 5 \mathrm{H}, \mathrm{Et}-$ $\mathrm{C}=) .5 .67(\mathrm{t}, J=0.8 \mathrm{~Hz}, 1 \mathrm{H}, \mathrm{H}-\mathrm{C}=)$. $2 \mathrm{a}(\mathrm{Si}):{ }^{1} \mathrm{H} \mathrm{NMR}(300 \mathrm{MHz}): \delta^{1} \mathrm{H}=0.13\left(\mathrm{~s}, 9 \mathrm{H}, \mathrm{Me}_{3} \mathrm{Si}\right)$, $1.21,0.93$ (q, t, $J=7.3 \mathrm{~Hz} .10 \mathrm{H}, \mathrm{Et}_{2} \mathrm{~B}$ ), 2.36, 0.92 (q, t, 5H, Et-C=), 5.85 (s, $1 \mathrm{H}, \mathrm{H}-\mathrm{C}=$ ).

Sodium 2-[(E)-1-trimethylstannyl-but-1-enyl]diethylhydridoborate 5 a and the $(Z)$-isomer 6a. Sodium hydride was filtered off from a suspension in mineral oil, washed repeatedly with pentane and dried in a vacuum. Then the powder of $\mathrm{NaH}(2.5 \mathrm{~g})$ was given into a Schlenk tube, suspended in hexane, $\mathrm{BEt}_{3}(0.5 \mathrm{~mL})$ was added, and the mixture was heated to reflux for $90 \mathrm{~min}$. At room temperature, a small amount of an 80:20 mixture of 1a and 2a $(0.86 \mathrm{~g}, 3 \mathrm{mmol})$ was added, and the mixture was kept stirring for $90 \mathrm{~min}$. The supernatant solution was decanted, and volatiles were removed in a vacuum, leaving a colorless oily material which was dissolved in $\mathrm{C}_{6} \mathrm{D}_{6}$ and characterized by NMR spectroscopy (Table 1). 5a: ${ }^{1} \mathrm{H}$ NMR $(300 \mathrm{MHz}): \delta^{1} \mathrm{H}$ $\left[{ }^{2} J\left({ }^{119} \mathrm{Sn},{ }^{1} \mathrm{H}\right)\right]=0.22[51.2]\left(\mathrm{s}, 9 \mathrm{H}, \mathrm{Me}_{3} \mathrm{Sn}\right), 0.17,0.95$ (q, t $\left.J=7.6 \mathrm{~Hz}, 10 \mathrm{H}, \mathrm{Et}_{2} \mathrm{~B}\right), 2.25,0.84$ (q, t, $J=7.3 \mathrm{~Hz}, \mathrm{Et}-\mathrm{C}=), 6.02[110.3](\mathrm{s}, 1 \mathrm{H}, \mathrm{H}-\mathrm{C}=) .6 \mathrm{aa}:{ }^{1} \mathrm{H}$ NMR $(300 \mathrm{MHz}): \delta \delta^{1} \mathrm{H}\left[{ }^{2} J\left({ }^{119} \mathrm{Sn},{ }^{1} \mathrm{H}\right)\right]$ $=0.24[51.2]\left(\mathrm{s}, 9 \mathrm{H}, \mathrm{Me}_{3} \mathrm{Sn}\right), 0.17,0.95$ (q, t, $\left.J=7.6 \mathrm{~Hz}, \mathrm{Et}_{2} \mathrm{~B}\right), 2.19,1.09$ (q, t, $J=7.3 \mathrm{~Hz}$, Et$=), 5.76[115.9](\mathrm{s}, 1 \mathrm{H}, \mathrm{H}-\mathrm{C}=)$.

\section{Acknowledgements}

Support of this work by the Deutsche Forschungsgemeinschaft is gratefully acknowledged.

\section{References}

1. (a) Pelter, A.; Smith, K.; Brown, H. C. Borane Reagents; Academic Press: London, 1988. (b) Brown, H. C. Organic Syntheses via Boranes; Wiley-Interscience: New York, 1975. (c) Ramachandran, P. V.; Brown, H. C.; Eds.; ACS Symp. Ser., 2001; 783; Organoboranes for Syntheses; ACS: Washington D. C., 2001.

2. (a) Miyaura, N.; Yamada, K.; Suginome, H.; Suzuki, A. J. Am. Chem. Soc. 1985, 107, 972.

(b) Miyaura, N.; Satoh, M.; Suzuki, A. Tetrahedron Lett. 1986, 27, 3745. (c) Suzuki, A. Pure Appl. Chem. 1991, 63, 419. (c) Ishiyama, T.; Nishijima, K.; Miyaura, N.; Suzuki, A. J. Am. Chem. Soc. 1993, 115, 7219. (d) Negishi, E.; Yoshida, T.; Abramovitch, A.; Lew, G.; Williams, R. M. Tetrahedron 1991, 47, 343. (e) Soderquist, J. A.; Rane, A. M.; Matos, K.; Ramos, J. Tetrahedron Lett. 1995, 36, 6847 
3. (a) Singleton, D. A.; Kim, K.; Martinez, J. P. Tetrahedron Lett. 1993, 34, 3071. (b) Wrackmeyer, B.; Wagner, K. Chem. Ber. 1989, 122, 857. (c) Suginome, M.; Ohmori, Y.; Ito, Y. J. Am. Chem. Soc. 2001, 123, 4601. (d) Onozawa, S.; Hatanaka, Y.; Tanaka, M. Chem. Commun. 1999, 1863. (e) Gerard, J. Hevesi, L. Tetrahedron 2004, 60, 367. (f) Suginome, M.; Ito, Y. J. Organomet. Chem. 2003, 680, 43.

4. Wrackmeyer, B. Coord. Chem. Rev. 1995, 145, 125.

5. Köster, R.; Seidel, G.; Wrackmeyer, B. Chem. Ber. 1989, 122, 1825.

6. Wrackmeyer, B.; Horchler, K.; Boese, R. Angew. Chem. Int. Ed.. 1989, 28, 1500.

7. (a) Wrackmeyer, B.; Kundler, S.; Boese, R. Chem. Ber. 1993, 126, 1361. (b) Wrackmeyer, B.; Kundler, S.; Milius, W.; Boese, R. Chem. Ber. 1994, 127, 333.

8. Wrackmeyer, B. Polyhedron 1986, 5, 1709.

9. Menz, G.; Wrackmeyer, B. Z. Naturforsch., Teil B, 1977, 32, 1400.

10. Brandsma L. Preparative Acetylenic Chemistry, $2^{\text {nd }}$ Edition, Elsevier, Amsterdam, 1988.

11. Wrackmeyer, B.; Bihlmayer, C.; Schilling M. Chem. Ber. 1983, 116, 3182.

12. Wrackmeyer, B.; Kerschl, S.; Klaus, U. Z. Naturforsch, Teil B, 2002, 57, 1251.

13. Wrackmeyer, B.; Horchler, K. Organometallics 1990, 9, 1881.

14. Köster, R.; Seidel, G.; Wrackmeyer, B. Chem. Ber. 1993, 126, 319.

15. Liang, C.; Allen, L. C. J. Am. Chem. Soc. 1991, 113, 1878.

16. (a) Dallaire, C.; Brook, M. A. Organometallics 1993, 12, 2332. (b) Dallaire, C.; Brook, M. A. Organometallics 1990, 9, 2873. (c) Lambert, J. B.; Zhao, Y.; Wu, H. J. Org. Chem. 1999, 64, 2729.

17. (a) Basso, N.; Goers, S.; Popowski, E.; Mayr, H. J. Am. Chem. Soc. 1993, 115, 6025. (b) Gabelica, V.; Kresge, A. J. J. Am. Chem. Soc.1996, 118, 3838.

18. Apeloig, Y.; Biton, R.; Abu-Freih, A. J. Am. Chem. Soc. 1993, 115, 2522.

19. Siehl, H.-U.; Kaufmann, F. P. J. Am. Chem. Soc. 1992, 114, 4937.

20. Berndt, A. Angew. Chem. Int. Ed. 1993, 32, 985.

21. (a) Binger, P.; Köster, R. Inorg. Synth. 1974, 15, 136. (b) Brown, H. C.; Khuri, A.; Kim, S. C. Inorg. Chem. 1977, 16, 2229.

22. Nöth, H.; Wrackmeyer, B. NMR Basic Principles and Progress, Nuclear Magnetic Resonance Spectroscopy of Boron Compounds; Diehl, P.; Fluck, E.; Kosfeld, R.; Eds.; Vol. 14; Springer: Berlin, 1978.

23. (a) Mann, B. E.; Taylor, B. F. ${ }^{13}$ C NMR Data for Organometallic Compounds; Academic Press: London, 1981. (b) Kalinowski, H.-O.; Berger, S.; Braun, S.; ${ }^{13}$ C-NMR-Spektroskopie, Thieme: Stuttgart, 1984.

24. Abragam, A. The Principles of Nuclear Magnetism, Oxford University Press: Oxford, 1961, pp. 305-315.

25. Wrackmeyer, B. Progr. NMR Spectrosc. 1979, 12, 227.

26. (a) Sanders J. K. M.; Hunter, B. K. Modern NMR Spectroscopy, $2^{\text {nd }}$ Edition, Oxford University Press: Oxford, 1993, Ch. 6. (b) Stott K.; Keeler, J.; Van Q. N.; Shaka, A. J. J. Magn. Reson. 1997, 125, 302. 
27. Mitchell, T. N.; Kummetat, C. J. Organomet. Chem. 1978, 157, 275.

28. Wrackmeyer, B. Annu. Rep. NMR Spetcrosc .1985, 16, 73. (b) B. Wrackmeyer, Annu. Rep. NMR Spectrosc. 1999, 38, 203.

29. (a) Morris, G. A.; Freeman, R. J. Am. Chem. Soc. 1979, 101, 760. (b) Morris, G. A. J. Am. Chem. Soc. 1980, 102, 428. (c) Morris, G. A. J. Magn. Reson. 1980, 41, 185. (d) Burum, D. P.; Ernst, R. R. J. Magn. Reson. 1980, 39, 163.

30. Gaussian 03, Revision B.02: Frisch, M. J.; Trucks, G. W.; Schlegel, H. B.; Scuseria, G. E.; Robb, M. A.; Cheeseman, J. R.; Montgomery, J. A. Jr.; Vreven, T.; Kudin, K. N.; Burant, J. C.; Millam, J. M.; Iyengar, S. S.; Tomasi, J.; Barone, V.; Mennucci, B.; Cossi, M.; Scalmani, G.; Rega, N.; Petersson, G. A.; Nakatsuji, H.; Hada, M.; Ehara, M.; Toyota, K.; Fukuda, R.; Hasegawa, J.; Ishida, M.; Nakajima, T.; Honda, Y.; Kitao, O.; Nakai, H.; Klene, M.; Li, X.; Knox, J. E.; Hratchian, K. P.; Cross, J. B.; Adamo, C.; Jaramillo, J.; Gomperts, R.; Stratmann, R. E.; Yazyev, O.; Austin, A. J.; Cammi, R.; Pomelli, C.; Ochterski, J. W.; Ayala, P. Y.; Morokuma. K.; Voth, D. A.; Salvador, P.; Dannenberg, J. J.; Zakrzewski, V. G.; Dapprich, S.; Daniels, A. D.; Strain, M. C.; Farkas, O.; Malick, D. K.; Rabuck, A. D.; Raghavachari, K.; Foresman, J. B.; Ortiz, J. V.; Cui, Q.; Baboul, A. G.; Clifford, S.; Cioslowski, J.; Stefanov, B. B.; Liu, G.; Liashenko, A.; Piskorz, P.; Komaromi, I.; Martin, R. L.; Fox, D. J.; Keith, T.; Al-Laham, M. A.; Peng, C. Y.; Nanayakkara, A.; Challacombe, M.; Gill, P. M. W.; Johnson, B.; Chen, W.; Wong, M. W.; Gonzalez, C.; Pople, J. A. Gaussian, Inc., Pittsburgh PA (2003).

31. Wollinski. K.; Hinton, J. F.; Pulay, P. J. J. Am. Chem. Soc. 1990, 112, 8251.

32. Wrackmeyer, B.; Khan, E. Z. Naturforsch., Teil B, 2007, 62, in press. 